\title{
2 The prokineticin system: an interface between neural 3 inflammation and pain
}

\author{
4 Silvia Franchi ${ }^{1} \cdot$ Paola Sacerdote $^{\mathbf{1}} \cdot$ Alberto Panerai $^{1}$
}

A1

A3 A4
C) Springer-Verlag Italia 2017
Mamba snake and were initially described for their ability to induce gastrointestinal motility in rodents. Soon the mammal homologs of Bv8: the prokineticin 1 (PK1 or endocrine gland derived vascular endothelial growth factor, EG-VEGF) and PK2 (mammalian Bv8) were also described. All members of the PK family weigh approximately $8 \mathrm{kDa}$ and have a structural conserved motif characterized by an N-terminal AVITGA sequence, a Trp residue in position 24 and the presence of five disulfide bridges. These peptides activate two closely related G-protein coupled receptors: prokineticin receptor 1 and 2 (PKR1 and PKR2) that belong to the family of neuropeptide Y receptor and have an amino acid identity of $85 \%$.

PKs and their receptors are widely distributed in many human tissues such as ovary, testis, adrenal gland, placenta, uterus, brain, intestinal tract, heart, bone marrow and peripheral blood. This wide and strategic presence in the body tissues allows them to be involved in many biological activities and to coordinate complex behaviors like feeding, drinking, circadian rhythm, neurogenesis, angiogenesis, haematopoiesis [2-4] activating multiple intracellular signals such as mitogen activated protein kinase (MAPK), AKT and STAT3. Moreover, the presence of PK members (PK and PKRs) in immune cells and in the main stations involved in pain transmission makes PK important players in inflammation and pain pathophysiology.

\section{Prokineticins as regulators of inflammation}

A parallelism between the structure, size, signaling and biological activities of prokineticins and chemokine superfamily was soon suggested [5] and PKs are now recognized in all respects as chemokines. Lymphoid organs, circulating leukocytes and hematopoietic cells, synoviocytes and dendritic cells constitutively express

\begin{tabular}{|c|c|c|c|c|}
\hline & Journal : Large 10072 & Dispatch & 25-2-2017 & Pages: $\mathbf{4}$ \\
\hline & $\begin{array}{l}\text { Article No. : } \mathbf{2 8 7 5} \\
\text { MS Code : PANERAI }\end{array}$ & $\begin{array}{l}\square \\
\boldsymbol{V}_{\mathrm{CP}}^{\mathrm{LE}} \\
\end{array}$ & & $\begin{array}{l}\square \text { TYPESET } \\
\Downarrow \text { DISK } \\
\end{array}$ \\
\hline
\end{tabular}


moderate levels of prokineticins [6,7] and their levels are increased in inflamed tissues [7].

We demonstrated that the administration of Bv8 (a valuable research tool to study PK system) in mice induced a proinflammatory phenotype stimulating macrophage chemotaxis and proinflammatory cytokine release [8] and skewing a Th1/Th2 balance towards a Th1 response [9]. A similar effect was also described for human monocytes. Our studies demonstrated that these effects are mediated by PKR1 receptor with the involvement of a Gq protein [8]. Moreover, the literature suggests that multiple pathways are involved in PK signaling and PKRs can also couple to Gi and Gs proteins $[6,10]$.

In the last years, several papers described in animals and humans a direct correlation between alterations in PK system and the development of different inflammatory and autoimmune diseases suggesting that the PK antagonism could ameliorate the pathological condition. The involvement of PK system was described in a mice model of arthritis (collagen-induced arthritis, CIA) where the expression levels of PK2 and PKR2 were found to be elevated in the CIA joints due to the presence of macrophage cells in the synovial membrane and these levels correlated with the arthritis severity. The administration of a prokineticin receptor antagonist decreased or suppressed the severity of arthritis by inhibiting PK2-PKR2 signaling in macrophages and reducing the levels of proinflammatory cytokines [11].

Pedotti' group recently demonstrated a role of the PK system in multiple sclerosis, in an animal model (experimental autoimmune encephalomyelitis, EAE) and patients and showed how the use of a PKR antagonist could inhibit proinflammatory $\mathrm{T}$ cell responses and reduce neurologic signs and central nervous system damage in mice [12]. The role of PK was also suggested in the development of Psoriasis, a chronic systemic inflammatory and autoimmune skin disease [13]. The author demonstrated a positive PK2/IL-1 proinflammatory loop which sustained chronic inflammation and keratinocyte hyperproliferation. The knock-down of PK2 improved the inflammatory condition while PK2 overexpression aggravated psoriasis [13].

These results suggest that prokineticins appear strongly upregulated in inflammatory cells and sustain a positive inflammatory loop at the basis of the development of pathological condition.

\section{Prokineticins in nociceptive pain}

The first evidences of a pronociceptive role of PK were derived from the observation that systemic injection of Bv8 and PK2 in rodents induces hyperalgesia to mechanical and thermal stimuli $[1,14]$ by activating PKRs receptors localized in the main stations of pain pathway. Both PKR1 and PKR2 are expressed in the superficial layers of the spinal cord, dorsal root ganglia (DRG) and peripheral terminal of nociceptors. The release of the neuropeptides like calcitonine gene related peptide (CGRP) and substance $\mathrm{P}$ in the spinal cord $[1,15]$ together with TRPV1 sensitization in primary dorsal root ganglia (DRG) neurons [1] was primarily involved in the development of hyperalgesia. Experiments of co-localization indicated that the majority of PKR1-positive DRG neurons also express TRPV1 and a reduced response to $\mathrm{Bv} 8$ is observed in TRPV1 deficient mice. Moreover, $50 \%$ of the Bv8-responding DRG neurons also express neuromediators involved in pain processing such as substance $\mathrm{P}$ and CGRP and release them after Bv8/ PK exposure.

It was suggested that PKs are also able to modulate central pain mechanism. Maione and collaborators demonstrated that the microinjection of Bv8/PK into the periaqueductal grey (PAG) exerted a pronociceptive effect increasing the intrinsic GABAergic tone which, in turn, was responsible for the inhibition of PAG antinociceptive output neurons impinging on rostro ventromedial medulla (RVM) neurons [17].

Further studies conducted in mice lacking pkr1 or pkr2 or $\mathrm{pk} 2$ genes demonstrated a direct role of the prokineticin system in pain perception in fact all these genotypes were characterized by higher thermal, mechanical and tactile pain threshold in comparison to normal wild type mice $[18,19]$.

\section{Prokineticines in chronic pain (inflammatory and neuropathic pain)}

It has recently emerged that pathological pain development and maintenance are not confined only to changes in the activity of neuronal systems, but involve interactions between neurons, inflammatory immune cells, glial cells, as well as a wide cascade of pro- and anti-inflammatory cytokines [20]. In this view, PKs can be considered important modulators capable to interfere both with peripheral and central pain mechanism. Consistently in the last years, a role of the PK system was suggested in the development and maintenance of inflammatory and neuropathic pain. Negri [21] demonstrated in an animal model of chronic inflammation, Complete Freund Adjuvant (CFA), that inflammation was highly correlated with an overexpression of PK2 in the granulocytes that infiltrate the inflamed tissue and the up-regulation was responsible for inflammation-associated hyperalgesia [21]. The authors showed how the hyperalgesia induced by CFA was abolished by PC1, a non-peptidic PKR1 preferred antagonist.

Regarding neuropathic pain (NP), the involvement of prokineticins was investigated in different experimental animal models: NP derived from an injury of sciatic nerve: 
chronic constriction injury model (CCI) [22] and spared nerve injury [23], diabetes [24] and cancer-induced NP [25]. In all these models, the presence of aberrant pain well correlates with an increase of the levels of PK2 in the spinal cord, especially in activated astrocytes [22-24]. The treatment with a PK system antagonist like PC1 or with PK neutralizing antibody [25] was able to counteract thermal hyperalgesia and allodynia, reduce the injury-induced overexpression of PK2 and restore the physiological levels of proinflammatory and anti-inflammatory cytokines both in periphery and spinal cord.

\section{Conclusions}

The above presented evidences suggest that PK system plays a central role in the development and maintenance of inflammation and acute and chronic pain and indicate that the antagonism of the PKRs could represent a new pharmacological strategy to control pathological pain, acting at different levels. The PKR block may contrast the pronociceptive role of endogenous PK, reduce immune cells infiltration and neuroinflammation in the main pain stations, and prevent the release of CGRP and TRPV1 sensitization.

\section{Perspective: what about a possible role of prokineticins in migraine?}

Abundant evidences accumulated from animal and human have demonstrated that the activation of meningeal afferents, neuropeptide release, and neurogenic inflammation plays a pivotal role in the generation of pain in migraine headache. CGRP is no doubt a crucial player and upon stimulation, it is released not only at the nerve endings, where it mediates vasodilation via smooth muscle cell receptors and plasma extravasation [26] but also from the neuronal cell bodies in the trigeminal ganglia. It is now recognized that CGRP represents a regulator of the intraganglionic crosstalk between neurons and glial cells prompting an inflammatory cascade that could lead to sensitization throughout the release of proinflammatory cytokines and chemokines which in turn activate TRPV1 or purinergic P2X receptors. Moreover, recent evidences suggested that also in migraine a significant neuronal, glia, immune interaction exists and an involvement of proinflammatory cytokines in the pathophysiology of primary headaches is probable. As previously described, prokineticins induce CGRP release in the spinal cord and DRG and recent findings demonstrated that also the trigeminal ganglia can be a target for prokineticins. In fact the application of Bv8/PK to trigeminal ganglia significantly elevated their heat-induced CGRP release and immunohistochemistry experiments revealed a co-localization of PK2 and CGRP in the same trigeminal neurons [27]. It was also suggested that PK2 suppressed GABA activated current in trigeminal ganglion neurons [28]. All these evidences support the idea of the presence of prokineticin receptors in the vascular trigeminal system. In the same way, we cannot exclude the possibility that PKs may also directly sensitize meningeal nociceptors also by inducing proinflammatory cytokines release. Finally, we can speculate that PK may also sustain a central nervous system origin of migraine acting on PAG-RVM circuit [29].

Future studies aimed at identifying novel targets, such as PK system, in migraine will be of great importance, also considering that the treatment of this condition is still far from being satisfactory.

\section{Compliance with ethical standards}

Conflict of interest I certify that there is no actual or potential conflict of interest in relation to this article.

\section{References}

1. Mollay C, Wechselberger C, Mignogna G, Negri L, Melchiorri P, Barra D, Kreil G (1999) Bv8, a small protein from frog skin and its homologue from snake venom induce hyperalgesia in rats. Eur J Pharmacol 374(2):189-196

2. Negri L, Lattanzi R, Giannini E, De Felice M, Colucci A, Melchiorri P (2004) Bv8, the amphibian homologue of the mammalian prokineticins, modulates ingestive behaviour in rats. $\mathrm{Br} \mathbf{J}$ Pharmacol 142(1):181-191

3. Cheng MY, Bullock CM, Li C, Lee AG, Bermak JC, Belluzzi J, Weaver DR, Leslie FM, Zhou QY (2002) Prokineticin 2 transmits the behavioural circadian rhythm of the suprachiasmatic nucleus. Nature 417(6887):405-410

4. Ferrara N, Frantz G, LeCouter J, Dillard-Telm L, Pham T, Draksharapu A, Giordano T, Peale F (2003) Differential expression of the angiogenic factor genes vascular endothelial growth factor (VEGF) and endocrine gland-derived VEGF in normal and polycystic human ovaries. Am J Pathol 162(6):1881-1893

5. Monnier J, Quillien V, Piquet-Pellorce C, Leberre C, Preisser L, Gascan H, Samson M (2008) Prokineticin 1 induces CCL4, CXCL1 and CXCL8 in human monocytes but not in macrophages and dendritic cells. Eur Cytokine Netw 19(4):166-175

6. LeCouter J, Zlot C, Tejada M, Peale F, Ferrara N (2004) Bv8 and endocrine gland-derived vascular endothelial growth factor stimulate hematopoiesis and hematopoietic cell mobilization. Proc Natl Acad Sci USA 101(48):16813-16818

7. Dorsch M, Qiu Y, Soler D, Frank N, Duong T, Goodearl A, O'Neil S, Lora J, Fraser CC (2005) PK1/EG-VEGF induces monocyte differentiation and activation. $\mathrm{J}$ Leukoc Biol 78(2):426-434

8. Martucci C, Franchi S, Giannini E, Tian H, Melchiorri P, Negri L, Sacerdote P (2006) Bv8, the amphibian homologue of the mammalian prokineticins, induces a proinflammatory phenotype of mouse macrophages. Br J Pharmacol 147(2):225-234

9. Franchi S, Giannini E, Lattuada D, Lattanzi R, Tian H, Melchiorri $\mathrm{P}$, Negri L, Panerai AE, Sacerdote P (2008) The prokineticin 
receptor agonist Bv8 decreases $\mathrm{IL}-10$ and IL-4 production in mice splenocytes by activating prokineticin receptor-1. BMC Immunol 9:60

10. Lin DC, Bullock CM, Ehlert FJ, Chen JL, Tian H, Zhou QY (2002) Identification and molecular characterization of two closely related $G$ protein-coupled receptors activated by prokineticins/endocrine gland vascular endothelial growth factor. J Biol Chem 277(22):19276-19280

11. Ito H, Noda K, Yoshida K, Otani K, Yoshiga M, Oto Y, Saito S, Kurosaka D (2016) Prokineticin 2 antagonist, PKRA7 suppresses arthritis in mice with collagen-induced arthritis. BMC Musculoskelet Disord 17:387

12. Abou-Hamdan M, Costanza M, Fontana E, Di Dario M, Musio S, Congiu C, Onnis V, Lattanzi R, Radaelli M, Martinelli V, Salvadori S, Negri L, Poliani PL, Farina C, Balboni G, Steinman L, Pedotti R (2015) Critical role for prokineticin 2 in CNS autoimmunity. Neurol Neuroimmunol Neuroinflamm 2(3):e95

13. He X, Shen C, Lu Q, Li J, Wei Y, He L, Bai R, Zheng J, Luan N, Zhang Z, Rong M, Lai R (2016) Prokineticin 2 plays a pivotal role in psoriasis. EBioMedicine 13:248-261

14. Negri L, Lattanzi R, Giannini E, Metere A, Colucci M, Barra D, Kreil G, Melchiorri P (2002) Nociceptive sensitization by the secreted protein Bv8. Br J Pharmacol 137(8):1147-1154

15. De Felice M, Melchiorri P, Ossipov MH, Vanderah TW, Porreca F, Negri L (2012) Mechanisms of Bv8-induced biphasic hyperalgesia: increased excitatory transmitter release and expression. Neurosci Lett 521(1):40-45

16. Vellani V, Colucci M, Lattanzi R, Giannini E, Negri L, Melchiorri P, McNaughton PA (2006) Sensitization of transient receptor potential vanilloid 1 by the prokineticin receptor agonist Bv8. J Neurosci 26(19):5109-5116

17. de Novellis V, Negri L, Lattanzi R, Rossi F, Palazzo E, Marabese I, Giannini E, Vita D, Melchiorri P, Maione S (2007) The prokineticin receptor agonist $\mathrm{Bv} 8$ increases GABA release in the periaqueductal grey and modifies RVM cell activities and thermoceptive reflexes in the rat. Eur J Neurosci 26(11):3068-3078

18. Negri L, Lattanzi R, Giannini E, Colucci M, Margheriti F, Melchiorri P, Vellani V, Tian H, De Felice M, Porreca F (2006) Impaired nociception and inflammatory pain sensation in mice lacking the prokineticin receptor PKR1: focus on interaction between PKR1 and the capsaicin receptor TRPV1 in pain behavior. J Neurosci 26(25):6716-6727

19. Hu WP, Zhang C, Li JD, Luo ZD, Amadesi S, Bunnett N, Zhou QY (2006) Impaired pain sensation in mice lacking prokineticin 2. Mol Pain 2:35
20. Austin PJ, Moalem-Taylor G (2010) The neuro-immune balance in neuropathic pain: involvement of inflammatory immune cells, immune-like glial cells and cytokines. J Neuroimmunol 229(1-2):26-50

21. Giannini E, Lattanzi R, Nicotra A, Campese AF, Grazioli P, Screpanti I, Balboni G, Salvadori S, Sacerdote P, Negri L (2009) The chemokine Bv8/prokineticin 2 is up-regulated in inflammatory granulocytes and modulates inflammatory pain. Proc Natl Acad Sci USA 106(34):14646-14651

22. Maftei D, Marconi V, Florenzano F, Giancotti LA, Castelli M, Moretti S, Borsani E, Rodella LF, Balboni G, Luongo L, Maione S, Sacerdote P, Negri L, Lattanzi R (2014) Controlling the activation of the $\mathrm{Bv} 8$ /prokineticin system reduces neuroinflammation and abolishes thermal and tactile hyperalgesia in neuropathic animals. Br J Pharmacol 171(21):4850-4865

23. Guida F, Lattanzi R, Boccella S, Maftei D, Romano R, Marconi V, Balboni G, Salvadori S, Scafuro MA, de Novellis V, Negri L, Maione S, Luongo L (2015) PC1, a non-peptide PKR1-preferring antagonist, reduces pain behavior and spinal neuronal sensitization in neuropathic mice. Pharmacol Res 91:36-46

24. Castelli M, Amodeo G, Negri L, Lattanzi R, Maftei D, Gotti C, Pistillo F, Onnis V, Congu C, Panerai AE, Sacerdote P, Franchi S (2016) Antagonism of the prokineticin system prevents and reverses allodynia and inflammation in a mouse model of diabetes. PLoS One 11(1):e0146259

25. Hang LH, Luo H, Li SN, Shu WW, Chen Z, Chen YF, Yuan JF, Shi LL, Shao DH (2015) Involvement of spinal Bv8/prokineticin 2 in a rat model of cancer-induced bone pain. Basic Clin Pharmacol Toxicol 117(3):180-185

26. Schlereth T, Schukraft J, Krämer-Best HH, Geber C, Ackermann T, Birklein F (2016) Interaction of calcitonin gene related peptide (CGRP) and substance P (SP) in human skin. Neuropeptides 59:57-62

27. Hoffmann T, Negri L, Maftei D, Lattanzi R, Reeh PW (2016) The prokineticin $\mathrm{Bv} 8$ sensitizes cutaneous terminals of female mice to heat. Eur J Pain 20(8):1326-1334

28. Xiong YC, Li XM, Wang XJ, Liu YQ, Qiu F, Wu D, Gan YB, Wang BH, Hu WP (2010) Prokineticin 2 suppresses GABA-activated current in rat primary sensory neurons. Neuropharmacology 59(7-8):589-594

29. Panerai AE (2013) Is migraine a disorder of the central nervous system? Neurol Sci 34(Suppl 1):S33-S35

\begin{tabular}{|l|lll|} 
Journal : Large 10072 & Dispatch : 25-2-2017 & Pages : 4 \\
Article No. : $\mathbf{2 8 7 5}$ & $\square$ LE & $\square$ TYPESET \\
MS Code : PANERAI & $\sim_{\text {CP }}$ & $\checkmark$ DISK \\
\hline
\end{tabular}


Journal : 10072

Article : 2875

\section{Author Query Form}

算 Springer

the language of science

\section{Please ensure you fill out your response to the queries raised below and return this form along with your corrections}

\section{Dear Author}

During the process of typesetting your article, the following queries have arisen. Please check your typeset proof carefully against the queries listed below and mark the necessary changes either directly on the proof/online grid or in the 'Author's response' area provided below

\begin{tabular}{|l|l|l|}
\hline Query & Details Required & Author's Response \\
\hline AQ1 & $\begin{array}{l}\text { Please check and confirm the edit made to the sentence 'In the last years, several papers described in } \\
\text { animals and humans a direct correlation between alterations in PK system and the development of } \\
\text { different inflammatory and autoimmune diseases suggesting that the PK antagonism could ameliorate the } \\
\text { pathological condition' }\end{array}$ & $\begin{array}{l}\text { Reference [16] was provided in the reference list; however, this was not mentioned or cited in the } \\
\text { manuscript. As a rule, if a citation is present in the text, then it should be present in the list. Please provide } \\
\text { the location of where to insert the reference citation in the main body text. Kindly ensure that all } \\
\text { references are cited in ascending numerical order. }\end{array}$ \\
\hline AQ2
\end{tabular}

